\title{
POST-DEPENDENCE DISCOURSE IN THE LANGUAGE OF POLITICIANS OF PRAWO I SPRAWIEDLIWOŚĆ AND PLATFORMA OBYWATELSKA
}

\author{
Kamil Olechowski'
}

\begin{abstract}
The aim of this thesis was to analyze the speeches of politicians of the two largest Polish parties: Prawo i Sprawiedliwość and Platforma Obywatelska, using post-dependence theory. The work describes postcolonial and post-dependence theories, presents socially political divisions in the categories of right wing and left wing politics - and describes the methodological issues of critical discourse analysis. The subject of analysis in the research part of the thesis were politics' speeches on the following topics: the "Rodzina 500+" programme, terrorist attacks, the dispute with the Constitutional Court in Poland, Brexit and the Smolensk catastrophe. The goal of the analysis was to find the post-dependence discourse features.
\end{abstract}

Key words: post-dependence, politics, discourse

\section{Introduction}

In recent years, postcolonialism is one of the most popular theories within the humanities. Based on the interdisciplinarity and study of discourse, it tries to find in the texts the trace left by the difficult experience of being a subordinate. Originally it was addressed to analyze the discourse concerning the so-called Third World countries, which in their history were the subject of colonization by the Western countries.

The theory initiated by Edward Said in his book entitled Orientalism (1995) assumes the existence of a number of specific phenomena affecting the mentality and identity of society, which are reflected exactly in a discourse. These are, among others, inferiority complex towards the countries, which in the past dominated over the given community, or mythologized image of a given country before the occupation. The mentioned aspects relate to the so-called representatives of postcolonial states, however, postcolonial theory has also an interest in the practices of empires, that is, their discourse domination over (also the former) colony, which often leads to its unfair marginalization in the international arena.

Postcolonial theory is sometimes used in reference to the Polish experience. Nevertheless, this type of attempts of transferring this theory to Polish conditions met with criticism of a part of the scientific community, inlcuding Polish. As if in response to these problems, Post-Dependence Studies Center conducted reasearch that has been 
expressed in such publications as $(P)$ o zaborach, $(P)$ o wojnie, $(P)$ o PRL. Polski dyskurs postzależnościowy dawniej i dziś (Gosk, Krasowska, red., 2013) or Kultura po przejściach, osoby z przeszłością. Polski dyskurs postzależnościowy - konteksty i perspektywy poznawcze (Nycz, red., 2011). Post-dependence theory retains much of the works of Edward Said and other postcolonial theorists, however, it is not "loaded" with sometimes problematic terminology of post-colonialism, also, it is free from its historical connotations.

Is difficult to explicitly and decisively answer the question whether post-dependence or postcolonial theory is that right one in the case of Poland. Definitely it is not the author's ambition. For methodological clarity it should be noted, however, that the analyses included in this thesis are based primarily on post-dependence theory, although it was impossible to completely dissociate from the postcolonial perspective articulated in numerous scientific publications.

\section{Sampling}

The materials for analysis were selected on the basis of nonprobability sampling. By random sample, which was used in the article discussing post-dependence dimension of media discourse in two Polish newspapers: Gazeta Wyborcza and Rzeczpospolita, a body of research included also such texts, which, due to its subject, could not relate to post-dependence. Next to the essay about international relations, also other texts, for example, column about cooking, or film review were analyzed. In such situations, it is difficult to seek complexes associated with the experience of being subordinate (Olechowski, 2014, p. 50). Therefore, this time selected topics relate to the cases in which one can potentially expect major ideological differences between Platforma Obywatelska (known by its Polish initials as PO) and Prawo i Sprawiedliwość (known by its Polish initials as PiS): the "Rodzina 500+" programme, terrorist attacks, the dispute with the Constitutional Court in Poland, Brexit and the Smolensk catastrophe.

Television current affairs programs, which formula assumed participation of two politicians from the two opposing camps (PiS and PO), were analyzed. It may seem that it is easy to find programs, which meet these requirements; however, some problems appeared. For the programme Tak czy Nie, transmitted on TV Polsat, very often guests of extreme and radical views (often of marginal importance on the socio-political arena) are invited, in order to trigger off a heated discussion by polarization of opinions. This causes that relatively rare one can see in these programmes politicians and representatives of "the mainstream". In the case of Monika Olejnik's programme Kropka nad $i$ transmitted in TV TVN, the key selection of guests is not based on radicalism, but it happens very often that instead of politicians, various columnists or social activists are invited. That is why, among the analyzed materials dominates the programme Po przecinku, transmitted on public television. In this TV programme very often one can see the leadership team members, and also the representatives of the largest opposition party.

To provide the most recent materials, they are taken from the period when PiS took over power in Poland. The time range starts with the beginning of the VIII term of the Sejm (the lower house of the Polish parliament), that is, from 12 November 2015 and ends (for practical reasons) on 31 August 2016.

\section{The Rodzina 500+ programme (Family 500+)}

The Rodzina 500+ programme is the source of considerable controversy. On 1st April 2016, when the programme was implemented, it was discussed in the TV programme Tak czy Nie (Tak czy Nie - Czy program... 2016) by the two politicians: Marzena Okła-Drewnowicz (Platforma Obywatelska) and Janusz Szewczak (Prawo i Sprawiedliwość). 
At the beginning it is worth to focus on the statements of deputy Janusz Szewczak:

"(...) Indeed we have reached a historic moment, because in Poland it did not happened before that (...) Polish families with many children get 500PLN, 1 500PLN or 2 000PLN because these are the families (...) with four children. Well, it was not so before, really, this is the first time, when those Polish families with many children get something from the state, from the government. And it is not the situation that something is taken or limited. So this is really, really a historical event".

While it seems that the Rodzina 500+ programme could be considered as the most spectacular family-oriented programme implemented in the Third Polish Republic, yet, deputy Szewczak's statements are exaggerated, and therefore untrue. This applies especially to the section in which the deputy said that families in Poland never received support from the government. Such categorical opinion backfires on PiS. This political party often repeated that during period between 2005-2007, they pursued an effective profamily policy by adopting a new-baby bonus (the so called becikowe).

The allegation formulated by Mr Szewczak is even more surprising beacuse he is an economist. In this program, Mrs Okła-Drewnowicz also substantially countered him. She indicated that family policy concerns also building nurseries and extending maternity leave.

The statements of Mr Szewczak may be however understood in other way because they form a kind of a useful image from post-dependence point of view. Thanks to it, the so called Good Change policy programme is a kind of turning point in the recent history of Poland, being not only a new quality, but also, the interruption of the pathological system, which, from the perspective of supporters of Prawo i Sprawiedliwość, should be explicitly wrongly judged. Anyway, it is not the first time, the idea of "IV RP" (Fourth Polish Republic) is still most associated with the first rule of Prawo i Sprawiedliwość in 2005-2007, although it is not the only party that reffered to this slogan.

Such political perspective leads to the conclusion that PiS party is the only force that has the legitimacy to rule. So it does not concern the view that Kaczynski's party has a better program, more interesting concept of development or greater competence in managing the state apparatus, because such opinions are just as natural as the desire of political parties to take the power. PiS, according to this narration, does not pursue an effective profamily policy, but as the only one helps families with many children. In the extreme case of this rhetoric, it is PiS party, which is the independence of the Polish state, and the other political parties mean the loss of sovereignty.

Let us return to the discussion in the programme Tak czy Nie. The words "Poland" and "Poles" (in different genders and variously conjugated) were said by Mr Szewczak, in the first part of the programme, which was closely related to the Rodzina $500+$ programme, as many as 12 times. It seems that strong social character of PiS has no connection with the so-called "leftist sensibility," and it rather results from the national-patriotic attitude. It does not mean a Marxist idea of creating equal, classless society, but the emancipation of the Polish nation from the yoke of foreign capital. From this perspective indeed Poles liberated from the formal authority of a foreign country, but currently remain dependent on other countries in economic terms. Therefore, PiS is skeptical about the European Union (due to the easier capital flows between Member States), loudly opposed the limitations of carbon dioxide emissions into the atmosphere (because it is worth to save the "Polish mines" and use the rich resources that Poland owns) or makes a use of social transfers. The latter are thus a kind of a tool to fight for the Poles independence from the foreign capital. Besides, it is confirmed by the words of Mr Szewczak: "(...) there is money in Poland, but so far, it was not mainly for the Poles or the Polish families (...)".

Postcolonial and post-dependence societies are struggling with various problems, 
not only identity or mental problems, but also with economic issues, that is, the lack of money in the economy, or with a certain backwardness of civilization. At the time of Platforma Obywatelska's rule, main solution to these problems for Poland was close cooperation with the European Union, which funds enabled the rapid economic development - in extreme cases it may be an expression of the complex towards the West (due to Poles feeling of "worseness" towards citizens of more developed countries); the need to join the European community is seen here. On the other hand, there is an idea of PiS to support Polish families, thus become less dependent from the foreign help. In this case it can also be sometimes post-dependence complex; this time it is the fear of external influences, suspicion of any action of other countries. These are two solutions to the real problem, which source is a long period of being dominated by a foreign power.

Analyzing Mr Szewczak's statements, it is also possible to come to the conclusion that the main tool of economic policy of Prawo i Sprawiedliwość will be social transfers. Perhaps it is just a characteristic of the reviewed material; the topic concerned the programme involving the financial support for citizens by the state, thus the representative of PiS wanted to strongly emphasize the meaning of such activities. However, Mr Szewczak's statement that the Polish economy will not suffer, even if every Pole get 1000PLN more as additional grants, was an extreme and irresponsible populism.

On the other hand, it is worth to remember the words of the Minister of Development and Finance, Mateusz Morawiecki, who at a meeting with PiS's voters in Bydgoszcz stressed that the use of Rodzina 500+ programme is not the way to build prosperity of the country, and its implementation requires debt (Fabisiak, 2016). The ruling party is therefore aware of realization of decisions taken, although it is difficult to say to what extent other members of PiS share the view of Minister Morawiecki.

There is still a need to analyze the speech of deputy Marzena Okła-Drewnowicz. Her words give the impression of being substantial; she does not attack the programme Rodzina $500+$ as such, but only its technical details. She also criticizes PiS of lavishing in the election campaign with promises, which are impossible to realize. In this case, it is difficult to say that the deputy stands on the other side of the barricades in post-dependence dispute; her criticism concerns the technical details of the programme, moreover she sees the need for profamily policy.

It seems that such rhetorical tactics was determined by the Poles' support for the programme Rodzina $500+$. This programme is perceived generally in a positive way, so in this case, it is difficult to critize it completely. There is also no place for arguments referring to the emotions of voters, rather they are in this case, entirely applied by PiS (that is why, in the analysis of Mr Szewczak's statement, one can notice "post-depenedence rhetoric"), which may refer to the positive aspects of profamily acitivities. For these reasons, the most pragmatic seems to be polemics based on the substantial arguments, with general consent for the validity of the proposed solutions, which was also applied by the deputy of Platforma Obywatelska in the analyzed discussion. This attitude may also be associated with attempts by the biggest opposition party to search for a new identity and new voters. Suffering two painful electoral defeats in 2015, PO was forced to change the political tactics. Initially, Platforma Obywatelska was the party of free-market position, they criticized the programme Rodzina 500+, calling it "free distribution", and today they propose to support with the amount of 500 PLN each the first child (in this case the abolition of the income threshold) (Wiceminister rodziny wytyka..., 2016).

All these factors determined the discourse exisiting in the analyzed material. Favorable for PiS and the programme Rodzina 500+, public sentiment forced the representative of PO to apply a balanced, gentle criticism focused mainly on the details, and it helped PiS deputy to highlight the party's strong concern over Poland, using the post-dependence complexes. 


\section{Immigrants}

When the German Chancellor Angela Merkel published in 2015 the great invitation for refugees from war-stricken countries, few people expected that it would end with perhaps the biggest crisis in the history of the European Union. The so-called immigration crisis, negatively affected the social and political support for the the German Chancellor, could also have an impact on the final result of the referendum on Brexit, as the British Prime Minister David Cameron claimed, (Cameron: Kryzys imigracyjny..., 2015), therefore, it has led to the increase of divisions within the European Union.

The refugee issue was discussed in Monika Olejnik's programme Kropka nad $i$ by Jacek Sasin (Prawo i Sprawiedliwość) and Andrzej Halicki (Platforma Obywatelska) (Armia stworzona z uchodźców..., 2015). Although this topic has been the subject for a long time, this time it was updated by a series of terrorist attacks in France, which took place on 13 November, 2015 (130 people died). The Islamic State confirmed to be responsible for these bloodiest acts of terror in the history of France.

For a long part of the discussion in the studio, the interlocutors were almost unanimous. They stressed the importance of security of Polish state, the need for implementation of the decision on the reception of refugees taken by the government of Ewa Kopacz, and more activity of institutions that can increase the security of all European Union countries. In the attitudes of visitors, but also in individual sentences, the differences could be seen, though they relate to more general assessment of the EU, which was manifested especially on the issue if it developed the appropriate tools and procedures that allow for effective identification of potential terrorists from a huge wave of refugees. In the first minutes of the programme no acute polemics took place, only marking a disagreement with views of the interlocutor.

Again (similarly to the debate on the programme Rodzina 500+) the rhetoric of politicians was determined by prevailing social mood in Poland. According to survey conducted by a nationwide panel research Ariadna, up to 2/3 of Poles are against reception of refugees from North Africa (Maliszewski, 2015). Particularly important is the fact that the reluctance of Platforma Obywatelska's voters for the reception of refugees (66\%) is slightly lower than among voters of Prawo i Sprawiedliwość (68\%).

Acute discussion began in the second half of the programme. It concerned the difference that shyly appeared already at the beginning of the discussion and was associated with the views on the role and the future of the European Union. It was particularly important issue for Andrzej Halicki, PO deputy, who returns to this thread after a while (as he noted indeed): "Mr Sasin said very important words, it was few minutes ago, but just to remind them: there is a need for more integration within actions of European Union ". Deputy Sasin immediately stated that he did not say that; and indeed his words, which concerned the issue of refugees, sounded differently: "There is a need for a coordinated European policy in this matter."

Here outlines the main axis of difference of views between Prawo i Sprawiedliwość and Platforma Obywatelska. The first of these parties is defined as a eurosceptic, while the other is pro-EU. One of the key words in the ideological dispute about the shape of the European Union is "integration". At one point, the journalist Monika Olejnik jokingly asks Mr Jacek Sasin, whether it is a word forbidden in the camp of PiS. He replied: "No, it depends on what we mean by it." It shows a certain ambiguity in the attitude of PiS towards the EU.

It seems that in the camp of PiS perfect European integration is an effective Union, able to lead coherent and effective actions, but without depth federalization and centralization of power in Brussels. The problem, however, lies in the fact that demanding from the EU carrying out decisive international politics, without tools and procedures, which would allow for the elaboration of a common position of all Member States, is an empty demand impossible to realize. 
Such contradiction was even noticed by Eurosceptic columnist Paweł Lisicki already in 2014, when efforts were made through international politics and sanctions to force Putin to withdraw from the territories of Ukraine. However, the European Union, unlike the United States, for reasons of lack of unanimity of all Member States, was unable to work out an unequivocal position against Russia's actions.

Lisicki wrote: "It strikes me still that those who complain onto this EU sluggishness and lethargy, at the same time do not want to, and rightly so, change its character. Heck, a decision has to be made finally. Also, I think that the so-called deepening of integration and taking the sovereignty from nation states is harmful. That belief in pan-European state is a dangerous fantasy and utopia. But if these things were so, it makes no sense to moan and complain about Brussels passivity. Quid pro quo. Who wants the Union to be as efficient as the US is, must consequently demand weakening of national sovereignty of individual countries, including Poland "(2014, p. 3).

This logic, however, is not present in the camp of Prawo i Sprawiedliwość. Chairman of this party, Jaroslaw Kaczynski, believes in the possibility of an alternative shape of the European Union that would connect the effectiveness of this body on the international arena and an enormous autonomy of Member States. He would like to make the Union a superpower, led by a president with strong rights to conduct foreign policy. The EU would have to act on the basis of a confederation of nation-states, with a strong, common European army, which would work with NATO. He points at the same time that each country could also have its own independent army (Kaczynski, 2016).

This vision of the EU in the camp of PiS may have its origin in the fear of this formation against Russia's influence. Fear, that has post-dependence sources (due to partitions and the People's Republic of Poland period (PRL)) and that demands solidarity of the EU countries in opposition to the Putin's state, despite a general disagreement for the deep integration within the European structures.

Firslty, it is worth to consider attitude of PiS towards Russia. It is a party that at one time was known for Russophobia, and its fear against Russian imperialism can be heard especially in the famous words said by Lech Kaczynski in Georgia, August 5, 2008: "Today Georgia, tomorrow Ukraine, the day after the Baltic states, then maybe it iss time for my country, Poland" (Dziś Gruzja, jutro..., 2014). Today, this statement might look impressively, especially in connection with the crisis in Ukraine. The simple conclusion from the observations of such events as the annexation of Crimea by Russia is to recognize, that in this country reborns expansive imperialism, which in the end will be a threat also for Poland.

Meanwhile, as indicated by Dr Paul Rojek, who deals with Russian philosophy, currently dominant political concepts of this country are different:

"No reasonable scenario of Russian behavior assumes landing of green men in our country. In none of my analyses of tendencies of Russian geopolitical thinking Poland is a direct aim of the expansion of Russia. As I indicated, the Euroasiatists treat us as a natural sphere of influence of Germany, with whom they hope to find a common language, and insularists consider us as part of uninteresting, a culturally foreign environment, which is separated from the Russia-Island with border countries belt" (Rojek, 2014 p. 104-105).

A tough common historical experience, such as Katyn or communism, has the impact on the perception of Russia by the Poles (Raport: wzajemne postrzeganie..., 2013). In the case of Prawo i Sprawiedliwość and its sympathizers, there is also the event of recent history: the Smolensk catastrophe. Nearly half of PiS voters believes that on 10th April, 2010 in Smolensk, there was not a disaster, but the coup (Połowa ankietowanych wyborców..., 2014).

In the case of Germany, there are also difficult historical experiences. In contrast to Russia, this country is more predictable and has similar civilization to Poland. For 
these reasons, PiS is a party torn in relation to the EU. On the one hand it has to protect Poland from the influence of Russia, and on the other hand it is perceived as a potential threat for sovereignty. It is a peculiar paradox: historical dependence on Russia directs the international policy of PiS towards the EU, but the fear of being dependent on foreign capital pushes the party from this organization.

In the case of Platforma Obywatelska it may be noted that while it is still trying to keep the label of Euro-enthusiasts, especially in the case of very general questions as yet legally unspecified European integration, still it is not so determined to statements on specific issues, such as the refugee problem. It should be noted, however, that PO is at least consistent in this case, and their attitude towards refugees has not changed since the declaration of the then Prime Minister Kopacz, who spoke about European solidarity, but also did not want to accept economic migrants, and stressed the need to secure the borders of the EU and to ensure Poland's security.

Pis instead rationalized and softened its rhetoric with regard to refugees in relation to the one used for the purposes of the election campaign. Political practice, however, was different: although PiS Prime Minister Beata Szydło formally did not cancel the declarations of the previous government, in practice, she refused their implementation, because of the lack of appropriate conditions (Szydło usztywnia stanowisko..., 2016).

Both deputies during the discussed programme Kropka nad $i$ tried to present a centrist position in the discussion about refugees, and they differ more in details. Their rhetoric sometimes failed to meet the real political actions. From the analyzed material emerges their moderate position on the refugee issue, which can be seen especially on the background of other radical statements, including Kazimiera Szczuka, whose simplified statement can be found on many Internet portals: "As it turns out, that most of them are terrorists, then we will worry," (Debata z udziałem..., 2015) or prof. Boguslaw Wolniewicz, who suggested that the solution to the problem of the refugees is to shoot the boat, on which they are trying to get to Europe (Prof. Wolniewicz: Zatapiać ..., 2015).

\section{The Constitutional Court}

The case of a deadlock on the issue of the Constitutional Court seems to be the most serious crisis during the rules of Beata Szydło's government. The Constitutional Court's case was discussed in the programme Po przecinku by Łukasz Schreiber (Prawo i Sprawiedliwość) and Borys Budka (Platforma Obywatelska) [Po przecinku $11 / 08 / 2016,2016]$. The Constitutional Court's judgment, which concerned the new Act of Constitutional Court signed by President Andrzej Duda on July 30, 2016, and having come into force on 16 August, updated the interview. The Constitutional Court considered it as partly unconstitutional. Deputy Borys Budka (PO) from the very beginning of the programme makes it clear, referring also to the Act:

"Completely unnecessary law. In fact, to solve this crisis there is a need for one decision of the president, comply with the judgment of 3rd December last year, which is the swearing of three judges, and the decision of the prime minister, which is to publish all, already at the moment 23 judgments of the tribunal. The Constitutional Court analyzed the Act of June 2015. One regulation was eliminated - on this basis two judges elected by the current majority rule, and should rule the three judges elected in the previous term".

In response, deputy Łukasz Schreiber (PiS) accused the Constitutional Court's president Rzepliński of unfairness and politicization of the dispute, and stated that the problem of the Constitutional Court has its origin in the activities of Platforma Obywatelska: "The problems that we have today are the aftermath of your decision, the decision of the Sejm of the previous term and the election by promotion of two judges. In this connection, unconstitutional was the choice of the five judges, and this led to further consequences". 
Deputy Schreiber recognizes the original source of the problem, but he does not want to abolish it. The proposal of his interlocutor strives to restore the situation prior to the enactment of the unconstitutional Act by PO of June 2015, which allowed them to choose five, instead of three judges. Besides, in the discussion Mr Schreiber prefers going into details that are irrelevant to the essence of the problem. One interesting accusation, formulated by deputy Schreiber, was the observation that PiS has already repeatedly changed their laws as dictated by the opposition, which is completely inflexible in the negotiations, and does not want in any way to soften its position. Indeed, next acts prepared by PiS were more consistent with the expectations of the opposition, though never on crucial issues, that is, first of all, the swearing of three judges selected by the PO-PSL coalition. Compromise by PiS concerned for example, the reduction of the Court's composition from 13 to 11 judges.

During the discussion, much more substantial sounds deputy Borys Budka, who in a clear manner presents his position, refers to the generally known facts, and his reasoning is consistent and logical. On this background, deputy Łukasz Schreiber performs less favourably. Indeed, he is trying to cite various arguments and evidences, which can prove validity of theses given by him, but he does it often in a chaotic manner by using a complicated, bureaucratic language.

Trying to analyze the conflict, one could say, that the crisis of the Constitutional Court, probably most effectively of all current problems, divides the Polish society into two post-dependence camps. Even for some time this conflict could be considered by PiS as beneficial for them. This party could in fact build a narration that the Constitutional Court was the last bastion of the old, broken system, which tries to prevent the activity of a "good change". What is more, at a time when this issue began to be publicised on the European forum, PiS could accuse the opposition of treason, and considered the threat of sanctions from the EU as a threat to a sovereign state.

For the needs of media, the opposition formulated message filled with post-dependence features. There were slogans about the end of democracy and claims that the crisis surrounding The Constitutional Court shows that Poland is still far from the Western democracies. It seems, however, that such statements are highly exaggerated, although contain an element of truth: the dispute over The Constitutional Court ruins this state institution, and it is not the best proof of a state of Poland's policy. Also on the mythical West (which supposedly should instruct Poland in matters of democracy), there were even more serious crises. Just to mention an example of Belgium, who during 2010-2011 by 541 days could not establish the government (Po 541 dniach ..., 2011), or dispute over the US Supreme Court, which is often compared to the Polish problem with TK (Henzel, 2016).

What seems to be important for this matter, is the fact, that although the Poles believe that PiS is wrong on the issue of The Constitutional Court (Sondaż "Rzeczpospolitej"..., 2016), yet the party does not lose support in the polls (Rośnie poparcie dla PiS..., 2016). Such a situation may cause that PiS will not see the need to settle the dispute.

As for the opposition, thanks to this crisis, it managed to activate a large number of people dissatisfied with the rule of Prawo i Sprawiedliwość. However, it is difficult to conclude that it helped to attract people from outside the circle of their voters. In marches organized by The Committee for the Defense of Democracy (Polish: Komitet Obrony Demokracji, KOD) take part people already reluctant to PiS. So far, the opposition lacks other ideas for the development of social emotions, and therefore the matter of The Constitutional Court will be still in the foreground of political dispute.

\section{The Smolensk Catastrophe}

From time to time, the Smolensk catastrophe again becomes a topic of conversation in journalistic programmes. In case of the analyzed material, the reason of the 
conversation (which took place on August 9, 2016) on a topic related to the Smolensk catastrophe, was the fact, that PiS began collecting money to be spent on the construction of the monument of Lech Kaczynski at Krakowskie Przedmieście in Warsaw. In the programme attended deputy Jacek Sasin (PiS) and Paweł Olszewski (PO) (Po przecinku 08/09/2016, 2016).

During the conversation Mr Sasin did not suggest that Smolensk might have been a coup, although his interlocutor tried to introduce this topic to discussion. Deputy Olszewski also tried to show moderation in this matter and stated that although he is opposed to building new monuments, he would have left those that already exist.

The topic about Smolensk ended in the programme after 5 minutes. What is interesting, in other programmes, which main themes were topics related to the Smolensk catastrophe, also occurred transfer of emphasis on other things, first of all the Constitutional Court. This may be due to the fact that PiS effectively silenced the issue of Smolensk during their rule, their rhetoric and action in this matter radically changed compared to the years when this party was in opposition.

An interesting topic during the programme took place at the very end, when the journalist asked guests to comment on the reports of prof. Cenckiewicz, that the Office of State Protection (Polish: Urząd Ochrony Państwa, UOP) was to lead to gas explosion in 1995, to get documents that could discredit Lech Walesa (President of Poland from 1990 to 1995).

For Jacek Sasin it was an opportunity to attack the former president. He mentioned about the special services in Polish People's Republic, which were active during his presidency. Deputy Olszewski questioned the reliability of the work of Prof. Cenckiewicz, and stressed that thanks to Lech Walesa, the two politicians could talk that the day in the studio. Both deputies took the positions that were predictable; it was not substantive conversation about facts, but even more ideological statement about Lech Walesa. There is a lack of balanced opinions and compromised views.

Such presentation of position is determined by the present political interest, but also the short time of the programme. The interlocutors, even if they wanted, they had no possibility to discuss in details the case of Lech Walesa, distinguishing between the bright and dark sides of his biography. It even does not change the fact that it also builds the message, and thus also outlines gently post-dependence division. On the one hand, PiS sees Walesa, as the man who collaborated with the Security Service of the Ministry of Internal Affairs (Polish: SB), which means that the Round Table was the only way for the communist nomenclature to maintain the authority; on the other hand PO wants to keep the myth of Walesa as a man almost crystal clear, who citing Walesa, "overthrew the communism." PiS is therefore the representative of the people, for whom the period of transformation was very difficult; while PO manifests over-optymism with conviction that the new, western, capitalist system is the best possible, and everything the former president did, was absolutely good for Poland. Opinions about Lech Walesa by politicians are also connected with the fact that the former president strongly criticizes PiS, which is beneficial for PO.

In the analyzed material is clearly visible, too, that a representative of PiS very cleverly uses the rhetoric, depending on the topic. In the case of topics about the Smolensk catastrophe he avoided controversial statements, while in the cases related to Walesa, he used more assertive tone, thanks to probably still alive in the public consciousness the memory of the so-called "Kiszczak's closet". It turned out, however, that the main post-dependence threads related to other topic than the one predicted in this study, and now, perhaps because of the timeliness of both matters, they are more associated with Lech Walesa than the Smolensk catastrophe. 


\section{Brexit}

On June 23, 2016 in the UK, there was a referendum in which the citizens of the United Kingdom decided if they country should leave the European Union structures. On the subject of Brexit in the programme Po przecinku talked MEP Julia Pitera (PO) and MEP Ryszard Czarnecki (PiS) (TVP Info: Ryszard Czarnecki ..., 2016).

At the very beginning of the programme MEP Pitera expresses her euro-enthusiasm: "What bothers me the most in this discussion, which takes place now, it is a permanent repetition about a crisis of the European Union. I always say that it is just like in life. If we will repeat that something bad happens to us, then finally something bad happens. I totally do not understand this philosophy, I must tell you that I think we are the most pessimistic within the European Union, when it comes to permanent repetition: about crises, about a collapse, about some need to do something, about some revolutions that have to be done, institutional ones. Let us stop doing this, because people who actually are going to talk about the shape of the European Union will not treat us seriously, as the people who permanently herald defeat. "

This statement is based largely on post-dependence complexes. The main content covers very general ideas of MEP Pitera about Polish relation to the EU. She does not refer to any specific facts, and she even contradicts them. It is difficult not to talk about the crisis at a time when for the first time in the history of the EU, Member State started the procedure for leaving its structures, as rightly pointed out MEP Czarnecki. According to MEP Pitera, criticism of the EU, dissatisfaction with its shape, has to discredit Polish politicians in the eyes of their European "serious" partners.

Meanwhile Euro-skepticism is not typically Polish phenomenon, in this aspect even more assertive are the Hungarians, and the British, who confirmed it with the decision of Brexit, and they often criticized the European community. It seems that this is an expression of post-dependence complex, which is revealed mainly to the mythical West, which at this point was replaced by the EU.

During the entire programme mostly strikes MEP Pitera thoughts' formulation. She adjusts and matches the facts to thesis created by her and adopt unambiguous interpretations, in which echoes thoughtless Euro-enthusiasm. 6 largest EU countries decided to discuss the matter of Brexit, without the other Member States, well, Poles also in the framework of this organization created some subgroups (MEP unfortunately did not clarified this statement). The British decided that their country has to leave the EU; referendums are suspected, in the end if in 1941 one would ask US citizens, if they should join the Second World War, they would say "no", so this argument is just a "wishful thinking", especially if we consider the Japanese attack on Pearl Harbor on 7th December, 1941. Besides, a similar logic would lead us to questioning the results of democratic elections; finally under them, in 1933 Adolf Hitler came to power.

MEP Pitera argues further: in a referendum if the UK either remaining a member of, or leaving, the European Union voted $75 \%$ of young people, who are, as MEP Pitera says "the future of the state." It seems that MEP Pitera notes that such statistics are not relevant to referendums, but she cites them to strengthen her argument. MEP Pitera does not believe too (although at this point she stresses that she may be wrong) that actually Brexit will happen, as she emphasized, the British are "horrified", their country would break up, so they collected over two million signatures for a new referendum. The most substantial argument is the one about the future of the United Kingdom, and in terms of the number of signatures, probably they are just from the people who earlier supported the United Kingdom's staying in the EU. There is still, however, a big group, which would be "against", because the British are in this case very divided. MEP Pitera also criticized PiS for the choice of allies within the EU: Britain, which leaves these structures, and the Hungarians. The latter, according to MEP Pitera, if they had to choose between Poland and the EU, they will choose the EU. As an argument for her reasoning she just said, "I 
guarantee." More substantial was a note about possibility of close cooperation with the Baltic countries, because, as MEP Pitera explained, they act within the alliance of the Nordic countries, so they will not be interested in joint activities with Poland. The PO representative also criticized Jaroslaw Kaczynski, who suggested that in connection with Brexit, the highest representatives of the EU should resign, which is obvious procedure in the countries of mature democracy.

It is worth to cite one more quote of MEP Pitera: "After all, I would propose to work out together a certain philosophy for a common functioning, and do not think that only our idea is the best one, and the ideas of others are bad". This quote is difficult to analyze in post-dependence terms, but in the context of the other comments it seems significant that the MEP again implicitly criticizes "us Poles" for considering our ideas as the best, and others' ideas as bad ones.

Comparing with MEP Pitera, MEP Czarnecki seems to be more rational; he indicates numbers and facts, quotes speeches, and outlines ideas of redevelopment of the EU. He manifests kind of a Euro-skepticism in relation to the European community; however, he is trying to base his opinion on reasonable assumptions and arguments.

During the analyzed conversation, post-dependence discourse very clearly appeared in the statements of MEP Pitera. Certainly, one can criticize Prawo i Sprawiedliwość for the vision of international politics, but it must be based on facts. Unfortunately, Pitera's rhetoric lacks tangible arguments, which were replaced by post-dependence complexes.

\section{Summary}

The analyzed material shows that Prawo i Sprawiedliwość softened rhetoric in a number of important issues, mitigated the excitement surrounding the Smolensk catastrophe and withdrew from the radicalism concerning refugees. On the other hand, the party leads a kind of battle with the Constitutional Court, which became the theme of disputes with the opposition.

As for post-dependence discourse, strong post-dependence features are visible only in two of the analyzed materials. They appeared in the programme, Tak czy Nie, during which, social programme Rodzina 500+ was discussed. PiS deputy Szewczak, who took part in the discussion, very clearly created his party as the only one that guards the interests of Poles, cares about the future of Poland, saves the nation's demographics and guards the independence of the State. The second programme filled with post-dependence complexes was programme Po przecinku, in which the issue of Brexit was discussed. MEP Pitera expressed a clear view of the world, which based on criticizing the actions of Poles in the EU and praising the European community. It should be noted that both of these talks are characterized not only by post-dependence discourse, but also by low merits.

It is also worth noting that the political parties have begun to choose very carefully people, who represent them in programmes, when it comes to debate with representatives of other parties. This is particularly evident on the example of PiS: instead of Antoni Macierewicz known for sharp statements, very often we can see a balanced Jacek Sasin.

The elections of October 25, 2015 introduced changes in Polish politics, not only evident ones, which concern the government. It seems for example that currently Platforma Obywatelska resigns from being in the opposition to Prawo i Sprawiedliwość on the "post-dependence principle". It distances from free-market slogans, changes rhetoric on immigration crisis, declares a separation from the demands of the Left. As it results from the analyzed material, PO is closer to PiS, at least on the rhetorical level. These parties still compete with each other, though sometimes, it is difficult to find differences between them. So far PO is trying to make political capital by posititioning 
as the largest "anti-PiS" party, without moving into serious ideological disputes on the social or economic level. These approaches seem to be pragmatic calculations related to the current, dominant social mood in Poland.

It seems that in place of "post-dependence opposition" in relation to PiS, which has been occupied by Platforma Obywatelska, can enter the party Nowoczesna (styled as .Nowoczesna; English: Modern) by Ryszard Petru. It has a distinctly free-market character and regarding the views it inclines to the left wing, although is trying to silence them.

Today it seems impossible to answer the question whether there will be a castling of PO and .Nowoczesna on the Polish political scene. There is still a lot of time until the next elections, and the decisions of voters are influenced by many factors: the ability of parties' communication, the strength of their structures (also at the local level), the dominant mood of the public, programme offer, etc.

Post-dependence complex will be a factor too, but time will tell how it will be decisive. Today, however, it can be seen that the sympathies of the mainstream media, which are defined as left-liberal, are rather on the side of .Nowoczesna than on Platforma Obywatelska's side, which may also have a significant impact on the final voters' decisions. Moreover, the election will be the argument "for" or "against" theses included in this thesis.

\section{References}

Armia stworzona z uchodźców? Sasin: to jest koncepcja, którą trzeba przedyskutować w UE (2015), [online: 20 August, 2016], http://www.tvn24.pl/kropka-nad-i,3,m/kropka-nad-i-armia-stworzona-z-uchodzcow,595032.html.

Cameron: Kryzys imigracyjny doprowadzi do wyjścia Wielkiej Brytanii z UE (2015), [online: 20 August, 2016], http://www.polishexpress.co.uk/cameron-kryzys-imigracyjny-doprowadzi-do-wyjscia-wielkiej-brytanii-z-ue/.

Debata z udziałem kandydatów na posłów z Krakowa (2015), [online: 22 August, 2016], http://audycje.tokfm. pl/odcinek/Debata-z-udzialem-kandydatow-na-poslow-z-Krakowa/29476\#.

Dziś Gruzja, jutro Ukraina, a później może Polska - Lech Kaczyński to przewidział (2014), [online: 22 August, 2016], https://www.youtube.com/watch?v=LEhJ-5xIJtg.

FABISIAK M. (2016), Morawiecki słowami ws. 500+ naraził się na krytykę wewnątrz PiS. „Premier jest wściekła", [online: 18 August, 2016], http://wiadomosci.wp.pl/kat,1329,title,Morawiecki-slowami-ws-500narazil-sie-na-krytyke-wewnatrz-PiS-Premier-jest-wsciekla,wid,18421046, wiadomosc.html.

GOSK H., KRASOWSKA E. red. (2013), (P)o zaborach, (P)o wojnie, (P)o PRL. Polski dyskurs postzależnościowy dawniej i dziś, Kraków.

HENZEL P. (2016), Konflikt o Sąd Najwyższy w USA podobny do sporu w Polsce o TK. Prof. Lewicki: jest analogia do wydarzeń sprzed 80 lat, [online: 8 September, 2016], http://wiadomosci.onet.pl/tylko-w-onecie/ konflikt-o-sad-najwyzszy-w-usa-podobny-do-sporu-w-polsce-0-tk-prof-lewicki-jest/l6y00y.

KACZYŃSKI J. (2016), Kaczyński: Musimy wyjść z inicjatywą zmian w UE, rozm. przepr. M. Szudłrzyński, [online: 22 August, 2016], http://www.rp.pl/Brexit/160629410-Kaczynski-Musimy-wyjsc-z-inicjatywa-zmianUE.html.

LISICKI P. (2014), Unijna pasywność, amerykańska sprawność, Do Rzeczy, nr 19/067.

MALISZEWSKI N. (2015), Sondaż: Polacy nie chcą przyjmować uchodźców, [online: 20 August, 2016], http:// wiadomosci.onet.pl/kraj/sondaz-polacy-nie-chca-przyjmowac-uchodzcow/q8tht5.

NYCZ R. red. (2011), Kultura po przejściach, osoby z przeszłością. Polski dyskurs postzależnościowy - konteksty i perspektywy poznawcze, Kraków.

OLECHOWSKI K. (2014), Postzależnościowy wymiar dyskursu medialnego na przykładzie publicystyki "Gazety Wyborczej" i „Rzeczpospolitej", Komunikacja Społeczna, nr 2.

Po przecinku 09.08.2016 (2016), [online: 9 September, 2016], http://vod.tvp.pl/26248556/09082016.

Po przecinku 11.08.2016 (2016), [online: 5 September, 2016], http://vod.tvp.pl/26292115/11082016. 
Połowa ankietowanych wyborców PiS wierzy w zamach w Smoleńsku (2014), [online: 12 September, 2016], http://www.tvn24.pl/wiadomosci-z-kraju,3/polowa-ankietowanych-wyborcow-pis-wierzy-w-zamach-wsmolensku,417093.html.

Prof. Wolniewicz: Zatapiać łódki z tak zwanymi imigrantami, a nie ratować (2015), [online: 22 August, 2016], https://www.youtube.com/watch?v=Xgq3krxxg0E.

Raport: wzajemne postrzeganie się Polaków i Rosjan nadal negatywne (2013), [online: 12 September, 2016], http://wiadomosci.wp.pl/kat,1342,title,Raport-wzajemne-postrzeganie-sie-Polakow-i-Rosjan-nadal-negatywne,wid,15391536, wiadomosc.html?ticaid=117b78.

ROJEK P. (2014), Przekleństwo imperium. Źródła rosyjskiego zachowania, Kraków.

Rośnie poparcie dla PiS, a Platforma wyprzedziła Nowoczesną. NOWY SONDAŻ (2016), [online: 8 September, 2016], http://wiadomosci.dziennik.pl/polityka/artykuly/525933,rosnie-poparcie-dla-pis-a-po-wyprzedzilonowoczesna-nowy-sondaz.html.

SAID E. (2005), Orientalizm, Poznań.

Sondaż „Rzeczpospolitej": Polacy po stronie Trybunału Konstytucyjnego (2016), [online: 8 September, 2016], http://wiadomosci.onet.pl/kraj/sondaz-rzeczpospolitej-polacy-po-stronie-trybunalu-konstytucyjnego/ yz86m0.

Szydło usztywnia stanowisko. Miało być 100 uchodźców, nie będzie żadnego (2016), [online: 22 August, 2016], http://wiadomosci.dziennik.pl/polityka/artykuly/516410,beata-szydlo-rzad-pis-uchodzcy-imigranci-stanowisko-zamachy-bruksela-belgia.html.

Tak czy Nie - Czy program „Rodzina 500 plus” zwiększy dzietność w Polsce? (2016), [online: 14 August, 2016], http://www.polsatnews.pl/wideo-program/tak-czy-nie-czy-program-rodzina-500-plus-zwiekszy-dzietnosc-w-polsce_6366617/.

TVP Info: Ryszard Czarnecki (PiS) vs Julia Pitera (PO) / Brexit, Po przecinku 26.06.2016 (2016), [online: 10 September, 2016], https://www.youtube.com/watch?v=1_vc6vk2vuE.

Wiceminister rodziny wytyka niekonsekwencję Platformie: Uznawali 500+ za rozdawnictwo, a teraz chcą rozdawać więcej (2016), [online: 19 August, 2016], http://telewizjarepublika.pl/wiceminister-rodziny-wytyka-niekonsekwencje-platformie-uznawali-500-za-rozdawnictwo-a-teraz-chca-rozdawac-wiecej,29206. html. 